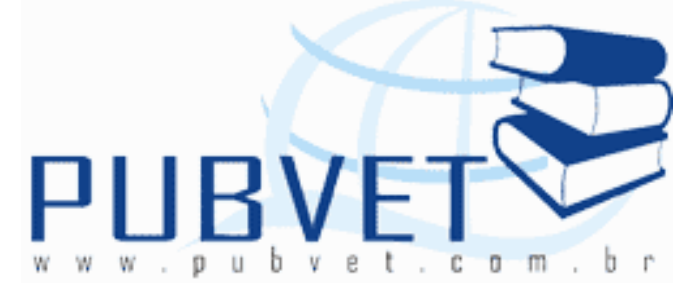

PUBVET, Publicações em Medicina Veterinária e Zootecnia.

\title{
Uso de diferentes aditivos em silagem de capim elefante (Pennisetum purpureum, Schum.)
}

\footnotetext{
Isaac Ferreira de Lima Junior ${ }^{1}$, Sharlyton Harysson Barbosa da Silva ${ }^{2 *}$, Anderson Neves Figueiredo ${ }^{1}$, Tania Marta Carvalho dos Santos ${ }^{2}$, Diogo Augusto Ferreira ${ }^{1}$, Marcos Elias Duarte ${ }^{1}$

${ }^{1}$ Mestrando do Programa de Pós-Graduação em Zootecnia - UFAL/Universidade Federal de Alagoas BR 104 NORTE 85 - MATA DO ROLO - 57100 - 000 - Rio Largo, AL - Brasil.

${ }^{2}$ Prof. Dr. UFAL/Universidade Federal de Alagoas BR 104 NORTE KM 85 - MATA DO ROLO - 57100 - 000 - Rio Largo, AL - Brasil

Trabalho de Conclusão de Curso do 10 Autor

${ }^{*}$ In memoriam
}

\section{Resumo}

Devido a sazonalidade da produção de forragem observada em várias partes do Brasil, e a importância da ensilagem como prática de conservação de forragem, objetivou-se elaborar uma compilação a respeito da prática da ensilagem, sobretudo do capim elefante (Pennisetum purpureum, Schum.), gramínea de alta produção forrageira e amplamente difundida em nossa região, esta revisão confronta as principais publicações relacionadas ao tema, abordando as características agronômicas dos principais grupos de cultivares de capim elefante (Grupos: Anão, Cameroon, Mercker, Napier e Híbridos), seus 
rendimentos para ensilagem e sua composição bromatológica. Sobre a prática da ensilagem foi feito amplo levantamento sobre os trabalhos que discutem suas etapas e a correlação entre a idade de corte para ensilagem e a qualidade da matéria obtida após o processo de ensilagem. Avaliação de indicadores de qualidade da silagem como teores de matéria seca (MS), Proteína Bruta (PB), nitrogênio amoniacal ( $\mathrm{N}-\mathrm{NH} 3$ ), poder tampão, carboidratos solúveis (CHOs) e $\mathrm{pH}$. Principais grupos de bactérias fermentadoras das silagens, bactérias ácidoláticas (BAL) e bactérias ácido-butíricas (BAB). Ampla literatura foi consultada para verificação dos principais aditivos atribuídos ao capim elefante e sua influência sobre os aspectos fermentativos, nutricionais e a digestibilidade da silagem obtida.

Palavras-chave: Ensilagem; Conservação; Forragem.

\title{
Use of different additives in elephant grass silage (Pennisetum purpureum, Schum.)
}

\begin{abstract}
Due to the seasonality of forage production observed in many parts of Brazil, and the importance of ensilage as fodder conservation practices, this work aimed to prepare a compilation about the practice of ensilage, especially the elephant grass (Penisetum purpureum Schum.), high grass forage production and widespread in our region, this review compares the major publications on the theme, addressing the agronomic characteristics of the main groups of cultivars of grass elephant (Groups: Dwarf, Cameroon, Mercker, Napier and Hybrid), its income for silage and its chemical composition. About the silage pratice was made complete survey of the work that discuss these stages and the correlation between the age of cut for ensilage and quality of material obtained after the ensiling process. Evaluation of indicators of silage quality and dry matter (DM), crude protein $(\mathrm{CP})$, ammonia $(\mathrm{NH} 3-\mathrm{N})$, buffering, soluble carbohydrates (WSC) concentration and $\mathrm{pH}$. Major groups of bacteria fermenting silage, lactic-acid bacteria (LAB) and butyric-acid bacteria (BAB).
\end{abstract}


There was a consult of extensive literature for main additives verification assigned to elephant grass and its influence on aspects fermentation, nutrients, digestibility and silage obtained.

Keywords: silage, storage, fodder.

\section{INTRODUÇÃO}

O comportamento sazonal da produção de forragem no nordeste leva a baixa produtividade da atividade pecuária nos períodos de estiagem, isto devido à escassez de alimento, conferindo assim importância à adoção de práticas de conservação de forragem, armazenando o excedente produzido durante o período chuvoso.

Dentre as práticas de conservação de forragem existentes; bastante comum é a prática da ensilagem, promovida através da conservação fermentativa da massa ensilada. Esta prática, no entanto, quando mal executada leva a depreciação do material armazenado, sobretudo por fermentações indesejáveis. Uma das espécies bastante utilizadas para a confecção da silagem é o capim elefante (Pennisetum purpureum, Schum.), bastante difundido em todo o Brasil e com notável produtividade, porém, o mesmo apresenta baixo nível de proteína e teores de matéria seca abaixo dos recomendados para a prática da ensilagem.

Rezende et. al, (2008) afirmam que após o milho e o sorgo, essa é uma das forrageiras tropicais que apresenta melhores características para se ensilar, em face de sua alta produtividade, elevado número de variedades, grande adaptabilidade, facilidade de cultivo, boa aceitabilidade pelos animais e, quando novo, bom valor nutritivo.

Para a melhoria das propriedades do capim elefante como forrageira destinada à ensilagem via de regra faz-se o uso de aditivos a fim de melhorar seus teores de matéria seca (MS) e proteína bruta (PB). Faria \& Corsi (1995), relataram que a técnica do uso de aditivos sólidos possibilita a ensilagem de 
plantas forrageiras cortadas com baixo teor de matéria seca, num processo simples em que as fermentações indesejáveis são facilmente controladas.

As características das forrageiras que favorecem uma boa fermentação são: o alto teor de matéria seca, a microflora epifítica e, principalmente, a quantidade de carboidratos solúveis. O milho e o sorgo são as duas gramíneas mais apropriadas para serem ensiladas, devido ao seu alto teor de carboidratos solúveis e alta produção de matéria seca. Todavia, alguns trabalhos têm mostrado que capins podem ser aproveitados, desde que se empreguem técnicas de pré-murchamento e aplicação de aditivos (Zanine et al., 2006).

Sendo assim muitos estudos vêm sendo efetuados no sentido de verificar a resposta de diversos aditivos sobre as qualidades fermentativa e nutricional das silagens de capins, em especial os pertencentes ao grupo elefante.

O presente trabalho consta de uma revisão bibliográfica que através da literatura, objetivou obter informações sobre o uso de diferentes aditivos em silagens de capim elefante (Pennisetum purpureum, Schum.).

\section{O CAPIM ELEFANTE}

O capim elefante (Pennisetum purpureum, Schum.), é um planta de origem africana muito utilizada no Brasil, tanto para formação de pastagens, como para a formação de capineiras, com sua utilização sob a forma de pastejo direto, e para consumo verde picado no cocho, respectivamente; Além de ser bastante utilizado para confecção de silagem e feno.

\subsection{ORIGEM E CLASSIFICAÇÃO BOTÂNICA}

Segundo Rodrigues et al. (2001), o capim elefante é originário do continente africano, mais especificamente da África tropical, entre $10^{\circ} \mathrm{N}$ e $20^{\circ} \mathrm{S}$ de latitude, tendo sido descoberto em 1905 pelo coronel Napier. Espalhou-se por toda África e foi introduzido no Brasil por volta de 1920, vindo de Cuba. Hoje, encontra-se difundido nas cinco regiões brasileiras. 
Conforme Tcacenco \& Botrel (1997) sua descrição original data de 1827, porém sofreu modificações ao longo do tempo. Atualmente, a espécie Pennisetum purpureum pertence à família Gramineae, sub-família Panicoideae, tribo: Paniceae, gênero: Pennisetum L. Rich e espécie: Pennisetum purpureum, Schumacher.

\subsection{DESCRIÇÃO MORFOLÓGICA}

Em consonância com diversos autores (Alcântara \& Bufarah, 1983; Nascimento Jr., 1981; Deresz, 1999) o capim elefante é descrito como uma gramínea perene, de hábito de crescimento cespitoso, atingindo de 3 a 5 metros de altura com colmos eretos dispostos em touceira aberta ou não, os quais são preenchidos por um parênquima suculento, chegando a $2 \mathrm{~cm}$ de diâmetro, com entrenós de até $20 \mathrm{~cm}$. Possui rizomas curtos, folhas com inserções alternas, de coloração verde escura ou clara, que podem ser pubescentes ou não, chegando a alcançar $10 \mathrm{~cm}$ de largura e $110 \mathrm{~cm}$ de comprimento.

As folhas apresentam nervura central larga e esbranquiçada, bainha lanosa, invaginante, fina e estriada, lígula curta, esbranquiçada e ciliada. Sua inflorescência é uma panícula primária e terminal, sedosa e contraída, ou seja, com rácemos espiciformes em forma de espiga, podendo ser solitária ou aparecendo em conjunto no mesmo colmo. A panícula tem, em média, $15 \mathrm{~cm}$ de comprimento, formada por espiguetas envolvidas por um tufo de cerdas de tamanhos desiguais e de coloração amarelada ou púrpura. Apresenta abundante lançamento de perfilhos aéreos e basilares, podendo formar densas touceiras, apesar de não cobrirem totalmente o solo. (Lopes, 2004).

\subsection{CARACTERÍSTICAS AGRONÔMICAS}

Alcântara \& Bufarah (1983), resumiram suas características agronômicas, onde pode-se encontrar suas principais adaptações e tolerâncias. Para 
complementar essa descrição, fez-se uso dos seguintes artigos: Rodrigues et al. (1987), Jacques (1994) e Moss (1964).

Das características agronômicas podemos destacar:

- Altitude - desde o nível do mar até 2.200 metros, sendo mais adaptada à altitudes de até 1.500 metros.

- Temperatura - de 18 a $30^{\circ} \mathrm{C}$, sendo $24^{\circ} \mathrm{C}$ uma boa temperatura. Porém é importante a amplitude dessa temperatura. Dependendo da cultivar, pode suportar o frio e até geadas.

- Precipitação - De 800 a 4.000 mm. Vegeta em regiões quentes e úmidas com precipitação anual de mais de $1.000 \mathrm{~mm}$, porém o mais importante é sua distribuição ao longo do ano, por ser uma forrageira muito estacional, onde 70-80 \% de sua produção ocorre na época das águas. Possui baixa tolerância à seca, podendo atravessar a estação seca com baixa produção se possuir raízes profundas (bem estabelecida).

- Radiação - Difícil de se saturar, mesmo em ambientes com elevada radiação. Possui alta eficiência fotossintética.

- Solo - Adapta-se a diferentes tipos de solo, com exceção dos solos mal drenados, com possíveis inundações. É encontrado em barrancas de rios, regiões úmidas e orlas de floresta. Não foram observados registros de tolerância à salinidade.

- Topografia - Pode ser cultivada em terrenos com declives de até $25 \%$ devido ao seu baixo controle da erosão do solo.

- Produção - relatos de produções de 300 toneladas de matéria verde por hectare são encontrados, mas a média nacional encontra-se bem baixo desta.

- Fertilidade - exigente em relação aos nutrientes; e não tolera baixo pH e alumínio no solo. 
- Propagação - por via vegetativa, utilizando-se colmos; poucas sementes são viáveis, tendo um valor cultural próximo a $30 \%$.

- Consórcio - devido à sua agressividade é difícil consorciar-se a leguminosas, porém, quando mantida próximo aos $60 \mathrm{~cm}$, pode facilitar o estabelecimento de leguminosas, como soja, siratro, kudzu, dentre outras.

\subsection{GRUPOS DAS CULTIVARES:}

As cultivares têm sido divididas em grupos de acordo com a época de florescimento, pilosidade da planta, diâmetro do colmo, formato da touceira, largura da folha, número e tipo de perfilhos (Carvalho et al., 1972; Bogdan, 1977; Pereira, 1993), considerando as principais características com função discriminatória e importância agronômica, bem como a constituição genética, definindo-se grupos com relação aos tipos básicos como citado por Lopes (2004):

- Grupo Anão: as cultivares deste grupo são mais adaptadas para pastejo em função do menor comprimento dos entrenós. As plantas desse grupo apresentam porte baixo $(1,5 \mathrm{~m})$ e elevada relação lâmina:colmo. Um exemplo é a cultivar Mott.

- Grupo Cameroon: apresentam plantas de porte ereto, colmos grossos, predominância de perfilhos basilares, folhas largas, florescimento tardio (maio a julho) ou ausente, e touceiras densas. Têm-se como exemplo as cultivares Cameroon, Piracicaba, Vruckwona e Guaçú.

- Grupo Mercker: Caracterizado por apresentar menor porte, colmos finos, folhas finas, menores e mais numerosas, e época de florescimento precoce (março a abril). As cultivares Mercker, Mercker comum, Mercker Pinda fazem parte deste grupo. 
- Grupo Napier: As cultivares deste grupo apresentam variedades de plantas com colmos grossos, folhas largas, época de florescimento intermediaria (abril a maio) e touceiras abertas. Têm exemplares como as cultivares Napier, Mineiro e Taiwan A-146.

- Grupo dos Híbridos: Resultantes do cruamento entre espécies de Pennisetum, principalmente Pennisetum purpureum e Pennisetum americanum. A identificação das cultivares é importante, pois permite uma recomendação mais próxima da correta, para o manejo e sistema de utilização.

\section{ENSILAGEM}

De acordo com Santos \& Zanine (2006), ensilagem é o método de preservação para a maioria das forragens. É baseado na conversão de carboidratos solúveis em ácidos orgânicos, principalmente lactato, por bactérias ácido-láticas (BAL). Como resultado, há redução do pH e o material, ainda úmido, torna-se livre da ação de microrganismos danosos.

No estádio inicial de fermentação, Lactococus como o Lactococcus lactis, Enterococcus faecalis, Pediococcus acidilactici, Leuconostoc mesenteroides, e Lactobacilos como os Lactobacilos plantarum e Lactobacilos cellobioses crescem juntamente com microrganismos aeróbicos, como as leveduras, fungos e bactérias aeróbicas, devido à presença de ar entre as partículas das plantas. Ao mesmo tempo, ocorre o processo de respiração das plantas. Para promover a fermentação um ambiente anaeróbio é formado, tornando predominante a população de bactérias ácido-láticas.

As BAL envolvidas são predominantemente Lactococos e Lactobacilos. As bactérias ácido-láticas são gram-positivas, não apresentam mobilidade nem produzem esporos, são catalase negativas. O produto final da fermentação é o ácido lático, entretanto, alguns grupos produzem quantidade considerável de 
$\mathrm{CO}_{2}$, etanol e outros metabólitos, sendo estas denominadas de heterofermentativas. Particularmente, Lactobacillus plantarum são os maiores fermentadores da silagem (Ohmomo et al., 2002).

No estádio final da fermentação, Lactobacilos tornam-se predominantes, devido à sua tolerância à acidez do meio. Não obstante, as BAL nas silagens são bem diversificadas, dependendo das propriedades dos materiais das plantas, tecnologia de ensilagem e tipo de silo. Geralmente, ocorre a mudança de predominância na silagem em seu estádio final de fermentação, de Lactococos para Lactobacilos, mas pode ocorrer predominância de Lactococos em alguns casos (Ohmomo et al., 2002).

No processo fermentativo da ensilagem é fundamental a presença de carboidratos solúveis (CHOs) para promover bom padrão de fermentação. Pois os mesmos, se constituem na fonte mais comum de energia para as bactérias produtoras de ácido láctico. Portanto, a quantidade e a rapidez na formação deste ácido depende da maior disponibilidade de açúcares nas forragens (Silveira, 1975).

Segundo Kearney \& Kennedy (1962), a porcentagem de carboidratos solúveis deve ser em média $15 \%$ na matéria seca do material ensilado. Porém McCullough (1977) afirmou que para se produzir silagens lácticas, as forrageiras devem apresentar um conteúdo de $\mathrm{CHO}$ solúveis superior a $8,5 \%$, e Catchpoole \& Henzel (1971), concluíram que são necessários de 13 a 16\%.

Já McDonald (1981) afirma que a silagem pode ser considerada de boa qualidade quando o material apresenta $\mathrm{pH}$ igual ou inferior a 4,2; ácido butírico igual ou inferior a $0,2 \%$, e nitrogênio $(\mathrm{N})$ amoniacal como porcentagem do $(\mathrm{N})$ total, igual ou inferior a 12,0\%. McCullough (1977), salienta a necessidade do conteúdo de matéria seca entre 28 a 34\%, para que ocorra boa fermentação no silo. Ohmono et al. (2002), recomenda para uma silagem de bom valor nutricional conteúdo de matéria seca de 35-40\% e conteúdo de açúcar no material maior que $2 \%$. 


\subsection{FASES DO PROCESSO DE ENSILAGEM}

Em uma compilação de trabalhos a respeito da prática da ensilagem em gramíneas Santos \& Zanine (2006) descrevem os seguintes processos:

- Fase aeróbia: ocorre durante o enchimento e se prolonga até poucas horas depois do fechamento do silo. A elevada concentração de $\mathrm{O}_{2}$ favorece $\mathrm{o}$ crescimento de microorganismos aeróbicos, como fungos, leveduras e algumas bactérias. A atuação destes microorganismos, juntamente com o processo respiratório da planta, promove redução do $\mathrm{O}_{2}$ e dá início a segunda fase.

- Fase de fermentação ativa: nesta fase há queda acentuada do $\mathrm{pH}$ da silagem devido à formação de ácidos orgânicos, a partir de açúcares. Inicialmente, atuam enterobactérias e bactérias heterofermentativas, posteriormente, tornam-se dominantes as homofermentativas. Esta fase se prolonga até que o $\mathrm{pH}$ caia para valores abaixo de 5,0.

- Fase de estabilidade: $O$ pH ácido da silagem e a condição de anaerobiose conservam a mesma até o momento da abertura do silo. Nesta fase, somente as bactérias ácidas lácticas se encontram em atividade, porém muito reduzida.

- Fase de descarga: ocorre por ocasião da abertura do silo, e a exposição de elevadas concentrações de $\mathrm{O}_{2}$, normalmente favorece o crescimento de fungos e leveduras. É chamada de estabilidade aeróbia, a propriedade de inibição da proliferação de fungos e leveduras, após o contato com o $\mathrm{O}_{2}$.

As mudanças químicas gerais em silagens, como resultado de enzimas bacterianas e das plantas, são a conversão de carboidratos em outros componentes, como ácidos orgânicos e gases, bem como a quebra parcial da proteína que resulta na formação de estruturas não protéicas. Estas mudanças 
que ocorrem resultam da interação de um número de espécies de bactérias e são muito influenciadas pela quantidade e tipo de substrato (McDonald et al. 1981)

\section{SILAGEM DE CAPIM ELEFANTE}

Apesar de ser relativamente fácil obter silagens de milho ou sorgo de alta qualidade, é também possível conseguir silagens de capim, principalmente de elefante, de qualidade razoável. Esta gramínea vem se destacando para ensilagem em face de sua alta produtividade, elevado número de variedades, grande adaptabilidade, facilidade de cultivo, boa aceitabilidade pelos animais e bom valor nutritivo, quando no estádio inicial de desenvolvimento.

Considerando que à medida que avança o estádio de desenvolvimento das gramíneas, há aumento da produção de matéria seca e, em contrapartida, ocorre redução no valor nutritivo, ao se realizar a ensilagem de capim elefante deve-se aliar alta produção por área e elevado valor nutritivo. Estas duas características, que alguns denominam equilíbrio nutritivo, são observadas no capim elefante quando cortado aos 50-60 dias de desenvolvimento (Lavezzo, 1985).

Embora o equilíbrio nutritivo do capim elefante seja alcançado aos 50-60 dias de desenvolvimento, deve-se ressaltar que nestas condições, alguns fatores poderiam ser considerados como limitantes para obtenção de silagens de boa qualidade. Entretanto, neste estádio de desenvolvimento três fatores limitam a obtenção de silagem de boa qualidade, que são: alto teor de umidade, baixo teor de carboidratos solúveis e o alto poder tampão.

Estes itens segundo McDonald et al. (1981), influenciam negativamente no processo fermentativo impedindo que haja um rápido decréscimo do $\mathrm{pH}$ a níveis adequados ( 3,8 a 4,2 ), fazendo com que fermentações secundárias e indesejáveis ocorram devido a ação de bactérias produtoras de ácido butírico, que passarão a se desenvolver, utilizando o lactato produzido e açucares residuais. Como esse processo envolve a descarboxilação do ácido láctico, a 
concentração hidrogeniônica é diminuída, criando condições mais favoráveis às bactérias butíricas (gênero clostridium), que desdobram aminoácidos a ácido butírico, ácidos voláteis, aminas, amônia e gases, prejudicando assim, a qualidade do produto preservado (Lavezzo, 1985).

Um $\mathrm{pH}$ elevado indica perda de nutrientes, principalmente, proteínas resultando em material menos palatável e de odor desagradável (Faria, 1971). Altos níveis de amônia têm sido associados a um forte desdobramento de aminoácidos e, de acordo com a maioria dos pesquisadores, é uma indicação de silagens de baixa qualidade.

Diversos trabalhos realizados com capins do grupo elefante têm mostrado teores de matéria seca, na idade do equilíbrio nutritivo, muito aquém do mínimo estabelecido para obtenção de uma boa silagem.

Assim, para ensilar os capins do grupo elefante, cortados aos 50-60 dias de desenvolvimento, o fator básico e limitante na conservação do material é o excesso de umidade, uma vez que altos teores de água $(\geq 75 \%)$ foram significativamente correlacionados com os constituintes indicadores de baixa qualidade, ou seja, ácido butírico, bases voláteis e amônia (Archibald, 1953).

\subsection{ADIÇÃO DE SUBPRODUTOS NA ENSILAGEM}

Segundo Pizarro (1978), aditivos são substâncias, misturas ou combinações destas que quando adicionadas às forragens no momento da ensilagem podem promover melhorias na sua fermentação, aceitabilidade e valor nutritivo.

Entretanto, é fundamental lembrar que a utilização de aditivos não elimina os cuidados normais para obtenção de boas silagens (época de corte, compactação da forragem, vedação do silo, etc.). Deve-se, também, considerar alguns fatores em relação aos aditivos: custo e facilidade de aplicação, eficiência na fermentação e melhoria do valor nutritivo. Assim, o sucesso na utilização de aditivo na silagem de capim elefante depende da escolha de um material que atenda o grande porte dessas condições. 
Diversos subprodutos da agroindústria do processamento de sucos vêm sendo utilizados e estudados como aditivos na silagem do capim elefante. Uma das variáveis a ser melhorada é o teor de matéria seca (MS) do capim elefante que invariavelmente, é muito baixo na época ideal de corte. Vários trabalhos com subprodutos da agroindústria têm apresentado resultados interessantes, permitindo a confecção de silagens de capim elefante de boa qualidade.

Gonçalves et al. (2002) observaram que para cada $1 \%$ de adição do subproduto da acerola até o nível de $20 \%$ os teores de matéria seca das silagens sofreram elevações de 0,55 ponto percentual e com o $15 \%$ de adição, o teor mínimo de $30 \%$ citado como ideal foi atingido.

Em relação à proteína bruta os autores observaram um crescimento linear com a adição do subproduto da acerola, atingindo o nível máximo de 7,52\% ligeiramente apenas superior ao mínimo de 7\% necessário para a mantença dos ruminantes. (Silva \& Leão, 1979).

Neiva et al. (2002), trabalhando com o subproduto da goiaba, observaram que para cada $1 \%$ de sua adição na ensilagem do capim elefante, observou-se um acréscimo de 0,5 ponto percentual nos teores de matéria seca. Com a adição de $15 \%$, os teores de matéria seca já alcançavam 30,3\% estando dentro da faixa ideal para a adequada fermentação lática.

Em trabalho realizado por Cysne (2004), a adição do subproduto da graviola nas silagens de capim elefante promoveu incrementos nos teores de MS e proteína bruta (PB), não havendo alterações significativas no padrão fermentativo das silagens, porém causou ligeira elevação nos teores de fibra em detergente ácido (FDA) o que pode diminuir o valor nutritivo das mesmas. O subproduto da graviola elevou os níveis de extrato etéreo (EE) acima dos níveis desejados para alimentação de ruminantes. Assim, para se obter silagens com até $5 \%$ de $E E$, deve-se adicionar no máximo 2,63\% de subproduto da graviola ao capim elefante por ocasião da sua ensilagem.

Oliveira Filho et al. (2002), trabalhando com o subproduto da casca de abacaxi, verificaram elevações nos teores de matéria seca na silagem de capim elefante. O valor máximo atingido com adição de $20 \%$ do subproduto foi de 
28,89\%, chegando próximo ao nível ideal de 30\% de matéria seca. Já para os teores de proteína bruta, observou-se que a variação entre os níveis de adição de subproduto foi pequena $(8,39 \%$ a 9,54\%), o que foi atribuído à proximidade dos teores de proteína bruta do capim elefante e do subproduto do abacaxi.

A adição do subproduto de abacaxi desidratado (SAD) em níveis de até $14 \%$ da matéria natural da forragem melhora o valor nutritivo de silagens de capim-elefante e possibilita maiores consumos de matéria seca, proteína bruta, fibra em detergente neutro e energia digestíveis. A inclusão no nível de $14 \%$ de SAD proporcionou aumento de aproximadamente $95 \%$ no consumo de proteína bruta, o que pode justificar a utilização desse subproduto na ensilagem do capim-elefante, uma vez que as características nutricionais das silagens foram melhoradas (Ferreira et al., 2009).

Ferreira (2002) ao avaliar a adição do bagaço de caju na ensilagem do capim elefante, observou melhora em suas características fermentativas, bem como no valor nutricional e consumo das silagens. As silagens com adição de $24 \%$ de bagaço de caju apresentaram $24,64 \%$ de MS e $7,52 \%$ de PB já o nível de $36 \%$ de inclusão de bagaço de caju apresentou $22,96 \%$ de MS e $9,57 \%$ de PB.

Rezende et al. (2008) avaliando diferentes aditivos em silagem de capim elefante constataram efeito significativo na porcentagem de $M S(P<0,01)$. A amplitude dos teores de MS estiveram entre $26,92 \%$ ( $7 \%$ de polpa cítrica) e $23,22 \%$ (testemunha). Os maiores teores de MS foram encontrados nos tratamentos dos quais foram utilizados aditivos secos nas silagens, sendo 0 menor valor observado na silagem que utilizou o aditivo biológico seguido da testemunha. Quanto à variável $P B$ houve efeito dos tratamentos $(P<0,01)$. A amplitude dos teores de PB situou-se entre 7,00\% (testemunha) e 9,55 (7\% farelo de trigo).

Linhares et al. (2008) em experimento avaliou a forragem de jitirana (Merremia aegyptia) adicionada ao capim elefante, onde sua inclusão até $50 \%$, produziu ganhos de proteína bruta, extrato etéreo, resíduo mineral e energia 
bruta, no entanto, na medida em que se aumentou a adição de jitirana na silagem, verificou um decréscimo no teor de MS.

A utilização de casca de café, farelo de cacau ou farelo de mandioca na ensilagem de capim-elefante resulta em silagens com características fermentativas adequadas, contudo, tanto a casca de café como o farelo de cacau reduziram o valor nutritivo da silagem (Pires et al., 2009).

Em estudo sobre a adição de casca de café, Faria et al. (2010), concluíram a eficiência deste aditivo para reduzir a produção de efluente e quando incluída nos níveis de $18 \%$ e $24 \%$, moída e inteira, torna a produção de efluente da silagem quase nula. A casca de café moída é mais efetiva em reduzir a produção de efluente que a casca inteira, portanto, é recomendável seu processamento para inclusão em níveis mais baixos, 6 e 12\%, enquanto em níveis iguais ou superiores a $18 \%$, a moagem torna-se dispensável. A composição do efluente é influenciada pelos níveis de casca de café, pelo processamento e pelos dias de colheita do efluente.

\subsection{CONSUMO VOLUNTÁRIO E DIGESTIBILIDADE}

O valor nutritivo de um alimento está ligado ao consumo voluntário, digestibilidade e à eficiência pela qual os nutrientes são utilizados (Lavezzo et al., 1994). Porém o principal fator limitante para a produção de animais alimentados com silagens seria o nível de consumo voluntário.

O decréscimo no consumo de silagem é resultante de mudanças químicas, que ocorrem durante a fermentação no silo e os fatores mais importantes, a serem considerados na avaliação das silagens são; a porcentagem de matéria seca, o teor de ácido acético, ácido butírico e o de nitrogênio amoniacal (Silveira et al., 1980; Lavezzo et al., 1984).

Catchapoole \& Henzel (1971), afirmam que algumas forragens tropicais são de difícil ensilagem, o que pode proporcionar baixo coeficiente de digestibilidade do material ensilado. Porém vários autores ressaltam que a utilização de aditivos ou técnicas que visem melhorar a preservação da 
forragem antes da ensilagem pode melhorar a fermentação e reduzir a diminuição da digestibilidade.

Henrique \& Bose (1992), analisando o efeito de dois aditivos enzimobacterianos sobre a ensilagem do capim elefante cv. Guaçu, com 50 dias de desenvolvimento, apesar de não ter encontrado efeito dos aditivos sobre a qualidade da silagem, obtiveram ingestão de matéria seca para ovinos variando de 41,96 a 50,09 g/UTM (Unidade de Tamanho Metabólico = PV 0,75 ) e coeficientes de digestibilidade da matéria seca e matéria orgânica do capim elefante de 63,78 a $65,39 \%$.

Esses valores estão de acordo com os encontrados por Tosi (1977), citado por Henrique \& Bose (1992). Em trabalhos com as cultivares Napier, Taiwan A144, Mineiro e Vrukwona, ensilados com 60 dias de desenvolvimento e submetidos a diferentes tratamentos (testemunha, emurchecimento e ácido fórmico).

Silveira et al. (1980) encontraram um consumo médio de $37,6 \mathrm{~g} /$ UTM para silagem de capim elefante e esta baixa ingestão segundo os autores está associada ao excesso de umidade das silagens. Para os valores de digestibilidade aparente da matéria seca e matéria orgânica foram registrados médias de $54,44 \%$ e $58,62 \%$, respectivamente. Sendo que as maiores médias de consumo e digestibilidade foram encontradas para 0 tratamento com emurchecimento por 6 horas.

Esse mesmo resultado foi observado por Lavezzo et al. (1984) que não observaram diferença $(P>0,5)$ nos níveis de consumo de matéria seca, para as cultivares Mineiro e Vruckwona, submetidas aos tratamentos com emurchecimento por 8 hora, formol, ácido fórmico e mistura de "Viher".

Entretanto, os consumos de matéria seca das silagens emurchecidas $(42,44 \mathrm{~g} /$ UTM $)$, tenderam a serem maiores que aquelas tratadas com formol (38,12 g/UTM) e com ácido fórmico (35,84 g/UTM ). Em relação aos coeficientes de digestibilidade de matéria seca, verificaram diferença $(P<0,05)$ apenas entre as silagens com emurchecimento $(63,81 \%)$ e as tratadas pelo formol ( $55,67 \%)$ e formol + ácido fórmico (57,29\%). 
Sobrinho et al. (1998) utilizaram a cultivar Guaçu, para determinação do valor nutritivo das silagens confeccionadas com a forragem fresca e emurchecida (planta inteira e triturada), cortada nas idades de 50, 70 e 84 dias. Verificaram que as silagens confeccionadas com as forragens emurchecidas apresentaram maior consumo de matéria seca, não havendo, porém, alterações na porcentagem e no consumo de nutrientes digestíveis totais (NDT) e nos coeficientes de digestibilidade da matéria seca, proteína bruta, fibra bruta e extrativos não nitrogenados.

Andrade \& Lavezzo (1998), avaliando o consumo e a digestibilidade aparente da silagem de capim elefante, confeccionadas com adição de 0, 8, 16 e $24 \%$ de matéria seca de rolão de milho, farelo de trigo e sacharina na forragem verde do capim, observaram que a ingestão de matéria seca se eleva com o aumento dos níveis de aplicação dos aditivos na ensilagem. Com os coeficientes de digestibilidade da matéria seca não revelaram diferença entre aditivos e níveis de adição de matéria seca.

A casca de café, o farelo de cacau e o farelo de mandioca, quando utilizados no nível de $15 \%$ da matéria natural, melhoram o consumo de matéria seca da silagem de capim-elefante. A silagem de capim elefante com farelo de mandioca proporcionam melhor consumo de nutrientes digestíveis totais. O capim elefante ensilado com $15 \%$ de farelo de mandioca proporciona melhor desempenho em ovinos da raça santa inês, sendo a utilização de farelo de mandioca na silagem de capim-elefante uma alternativa viável na formulação de dietas para ovinos. O maior consumo de matéria seca $(1.000,4$ $\mathrm{g} /$ dia) pelos ovinos alimentados com silagem contendo $15 \%$ de farelo de mandioca pode ser explicado pelo menor teor de FDN da dieta $(44,9 \%)$, enquanto a dieta contendo casca de café apresentou maior teor de FDN $(52,8 \%)$ e menor consumo de matéria seca (Carvalho Jr. et al., 2009 ).

Em estudo sobre o uso do farelo de mandioca, Pires et al. (2009) constatou que sua adição reduz os componentes da parede celular e aumenta a digestibilidade in vitro da matéria seca das silagens de capim elefante. 
Lima et al. (1972) apresentaram dados comparativos entre silagens de sorgo, capim elefante, capim colonião, capim pangola e capim guatemala, obteve ganhos de peso somente com silagem de sorgo $(1,3 \mathrm{~kg})$ e com silagem do capim guatemala $(1,8 \mathrm{~kg})$ para carneiros, ao final de 17 dias.

Rezende et al. (2008) obtiveram resultados de digestibilidade in vitro da matéria seca (DIVMS) de $71,13 \%$ com adição de $7 \%$ de raspa de batata, resultado superior ao observado por Rezende \& Evangelista (2002), 60\% DIVMS em pesquisa com associação de $23 \%$ de planta de girassol na silagem de capim elefante. Nesta mesma pesquisa, quando se adicionou 7\% de MDPS obteve-se uma DIVMS de $64,74 \%$ sendo superior aos valores verificados por Evangelista et al. (1987) os quais estudaram o uso de $6 \%$ de milho desintegrado com palha e sabugo (MDPS) na forma de aditivo para produção de silagens de capim elefante tendo verificado uma DIVMS de $52 \%$.

Rodrigues (2005) trabalhando com silagem de capim-elefante adicionada de $7 \%$ de raspa de batata observou um valor de $62,68 \%$ de DIVMS, sendo que os valores encontrados neste trabalho adicionando a mesma quantidade de raspa de batata foram superiores (71,13\% DIVMS).

\section{CONSIDERAÇÕES FINAIS}

O uso de aditivos, definitivamente, consiste em prática de grande benefício à ensilagem de capim elefante (Pennisetum purpureum Schum.), garantindo a melhora de seu padrão fermentativo e, conseqüentemente, melhor composição nutricional. No entanto, a adição de subprodutos deve ser feita de maneira criteriosa observando os níveis limitantes a fim de evitar prejuízos ao processo fermentativo ou ao valor nutritivo da forragem.

Maiores estudos devem ser dedicados aos índices de digestibilidade e ao desempenho animal para melhor aferir a importância da silagem de capim elefante e o seu uso com aditivos, visando comparar sua eficiência produtiva e econômica com outras forragens ou práticas de conservação. 


\section{REFERÊNCIAS BIBLIOGRÁFICAS}

ANDRADE, J.B. \& LAVEZZO, W. Aditivos na ensilagem de capim elefante. III. Valor nutritivo e consumo voluntário e digestibilidade aparente em ovinos. Pesquisa Agropecuária Brasileira, v.33, n.12, p.2015-2023, 1898.

ALCÂNTARA, P.B., BUFARAH, G. Plantas forrageiras: gramíneas e leguminosas. São Paulo, Editora Nobel, $2^{a}$ ed., 1983, 150p.

ARCCHIBALD, J. G. Sugar and acids in grass silage. J. Dairy Sci., Illinois, 36(4): 385-390. 1953.

BOGDAN, A.V. Tropical pasture and fodder crops. Longman, New York, 1977, 475p.

CARVALHO, M.M., MOZZER, O.L., ENRICH, E.L., CONTIJO, V.P.M. Competição de variedades de híbridos de Capim elefante (Pennisetum purpureum) em um solo Hidromórfico de Sete Lagoas, Minas Gerais. Pesq. Agrop. Bras., v.7, p.39-45, 1972.

CARVALHO, M. M.; MOZZER, O. L.; ENRICH, E. S.; GONTIJO, V. P. M. de. Competição de variedades e lúbridos de capim Elefante (Pennisetum purpureum Schum) em solos hidromórfico de Sete Lagoas, Minas Gerais. Pesq. Agropec. Bras.; Ser. Zoot., 7: 39-45, 1972.

CARVALHO Jr, J. N. de.; PIRES, A. J. V.; SILVA, F. F. da.; VELOSO, C. M.; SANTOS-CRUZ, C. L. dos.; CARVALHO, G. G. P. de. Desempenho de ovinos mantidos com dietas com capimelefante ensilado com diferentes aditivos. R. Bras. Zootec., v.38, n.6, p.994-1000, 2009

CATCHAPOOLE, V.R. \& HENZEL, E.F. Silage and silage-making from tropical herbage species. Herbage Abstracts, v.41, n.3, p.213-221, 1971.

CYSNE, J. R. B. Valor nutritivo de silagens de capim elefante (Pennisetum purpureum Schum.) Com níveis crescentes de adição do subproduto da graviola (Anona muricata I.). 2004. 37 f. Monografia (Estágio curricular obrigatório) - Universidade Federal do Ceará, Fortaleza, 2004.

CONDE, A. Dos R. Efeito da adição de fubá sobre a qualidade da silagem de capim elefante cortado com diferentes idades. Viçosa, UFV, 1970. 28 p. (Tese Mestrado).

DERESZ, F. Utilização do capim-elefante sob pastejo rotativo para produção de leite e carne. Juiz de Fora, Embrapa-CNPGL, 1999, 29p. (Circular técnica 54).

EVANGELISTA, A. R.; TEIXEIRA, J. C.; BENTO, L. A. Uso do milho desintegrado com palha e sabugo na forma de aditivo para produção de silagem de capim elefante (Pennisetum purpureum Schum). In: REUNIÃO ANUAL DA SOCIEDADE BRASILEIRA DE ZOOTECNIA, 24., 1987, Brasília, DF. Anais... Brasília, DF: Sociedade Brasileira de Zootecnia, 1987. $190 \mathrm{p}$.

FARIA, V. P. de; MATTOS, W. R. S.; SILVEIRA FILHO, S.; SILVEIRA, A. C. Observações preliminares sobre três variedades africanas de capim-elefante (Pennisetum purpureum, Schum.): Taiwan A-241, Uruvkwona e Cameroon. In: REUNIÂO ANUAL DA SOCIEDADE BRASILEIRA DE ZOOTECNIA, 7, Piracicaba, 1970. Anais... Piracicaba, SBZ, 1970. P. 28-9.

FARIA, V. P. de. Efeito da maturidade da planta e diferentes tratamentos sobre a ensilagem de capim elefante (Pennisetum purpureum, Schum.) Variedade Napier. Piracicaba, ESALQ, 1971. 78p. (Tese de Doutorado). 
FARIA, D. J. G.; GARCIA, R.; TONUCCI, R. G.; TAVARES, V. B.; PEREIRA, O. G.; FONSECA, D. $M$ da. Produção e composição do efluente da silagem de capim-elefante com casca de café. R. Bras. Zootec., v.39, n.3, p.471-478, 2010.

FERREIRA, A. C. H.; NEIVA, J. N. M.; RODRIGUEZ, N. M.; CAMPOS, W. E.; BORGES, I. Avaliação nutricional do subproduto da agroindústria de abacaxi como aditivo de silagem de capim-elefante. R. Bras. Zootec., v.38, n.2, p.223-229, 2009.

FERREIRA, A. C. H. Valor nutritivo das silagens de capim elefante com diferentes níveis de subprodutos da indústria do suco de caju. 2002. 101 f. Dissertação (Mestrado) Universidade Federal do Ceará, Fortaleza, 2002.

GONÇALVES, J.S.; NEIVA, J.N.M.; PIMENTEL, J.C.M. et al.. Avaliação do valor nutritivo de silagens de capim Elefante (Pennisetum purpureum Schum) com diferentes níveis de subproduto da acerola (Malpighia glabra L.). Reunião Anual da SBZ, In: 39a. Recife, 2002. Anais...Recife, 2002.

GUTIERREZ, L. E. Identificação de carboidratos e ácidos orgânicos em quatro variedades de capim-elefante (Pennisetum purpureum, Schum), colhidos em três estágios de maturidade. Piracicaba, ESALQ, 1975. 103 p. (Tese de Mestrado).

HENRIQUE, W. \& BOSE, M.L.V. Efeito de aditivos enzimo -bacterianos sobre a qualidade da silagem de capim elefante (Pennisetum purpureum Schum.). R. Bras. Zootec., v.21, n.3, p.429-438, 1992.

JACQUES, A.V.A. Caracteres morfo-fisiológicos e suas aplicações como manejo. In: CARVALHO, M.M., ALVIM, M.J., XAVIER, D.F. et al. (Eds.) capim elefante: produção e utilização. Coronel Pacheco:Embrapa-Gado de Leite, 1994, p.31-47.

KEARNEY, P.C. \& KENNEDY, W.K. Relation ship betweem lasses of fermentable sugars and changes in organic acids of silage. Agronomy Journal, v.54, n.2, p.114-115, 1962.

LAVEZZO, W. Silagem de capim-Elefante. Inf. Agrop., Belo Horizonte, v.11, n.132, p 50-57, 1985.

LAVEZZO, W. Ensilagem de capim elefante. In: SIMPOSIO SOBRE MANEJO DE PASTAGENS, 10.,1994, Piracicaba. Anais... Piracicaba: ESALQ, 1994. p. 169-275.

LAVEZZO, W.; LAVEZZO, O.E.N.M.; SILVEIRA, A.C. Efeitos do emurchecimento, formol e ácido fórmico sobre o consumo e digestibilidade da silagem de capim elefante ( Pennisetum purpureum Schum. ). R. Bras. Zootec., v.13, n.4, p.501-508, 1984.

LIMA, C.R.; ARAÚJO, M.R.; SOUTO; S.M. 1972. Valores nutritivos da silagem de sorgo forrageiro e capins elefante, colonião, pangola e guatemala. Pesquisa Agropecuária Brasileira, v.7, p.53-57,1972.

LINHARES, P. C. F.; VASCONCELOS, S. H. L.; MARACAJÁ, P. B.; LIBERALINO FILHO, J.; NUNES G. $H$. de $S$. Inclusão de jitirana na composição químicobromatológica de silagem de capim-elefante. R. Caatinga (Mossoró,Brasil), v.21, n.3, p.01-05, julho/setembro de 2008.

LOPES, J. Valor nutritivo das silagens. In: SIMPÓSIO SOBRE MANEJO DA PASTAGEM. 2, Piracicaba, ESALQ, 1975. Anais...p. 187-218.

LOPES, B. A. O Capim - Elefante. Seminário apresentado à disciplina ZOO 645 (Métodos nutricionais e alimentação de ruminantes), Viçosa. 2004, 56p.

McCULLOUGH, M.E. Silage and silage fermentation. Feedstuffs, v.49, n.13, p. 49-52. 1977. 
McDONALD, P. . The biochemistry of silage. New York: John Wiley \& Sons. 226p. 1981.

MOSS, D.N. Some aspects of microclimatology important in forage plant physiology. In: Forage plant physiology an soil relationships. ASA Special publications Madison Winsconsin, 1964.

NASCIMENTO JR., D. Informações sobre plantas forrageiras. Viçosa, MG, UFVImprensa Universitária, 1981. 56p.

NEIVA, J.N.M.; VIEIRA, N.F.; PIMENTEL, J.C.M. et al.. Avaliação do valor nutritivo de silagens de capim Elefante ("Pennisetum purpureum" Schum.) com diferentes níveis de subproduto da goiaba (Malpighia glabra L.). Reunião Anual da SBZ, In: 39a. Recife, 2002.

OHMOMO, S.; TANAKA, O.; KITAMOTO, H.K.; CAI, Y. Silage and microbial performance, old history but new problem. JARQ 36 (2), 59 - 71 (2002) http://www.jircas.affrc.go.jp.

OLIVEIRA FILHO G.S.; NEIVA J.N.M.; PIMENTEL J.C.M. et al.. Avaliação do valor nutritivo de silagens de capim Elefante (Pennisetum purpureum Schum) com diferentes níveis de subproduto do abacaxi (Ananas comosus L., MERR.) In: REUNIÃO ANUAL DA SOCIEDADE BRASILEIRA DE ZOOTECNIA, 39, 2002, Recife, PE, 2002. Anais... Recife, SBZ, 2002. p. 1-3. (CD-ROM).

PEDREIRA, J. V. S.; BOIN, C. Estudo do crescimento do capim Elefante, variedade Napier (Pennisetum purpureum, Schum). Bol. Ind. Animal, Nova Odessa, 26: 263-73, 1969.

PEREIRA, A.V. Escolha de variedades de capim-elefante. In: In: PEIXOTO, A.M., MOURA, J.C., FARIA, V.P. (Eds.) Simpósio sobre Manejo da Pastagem, 10, Piracicaba, 1993. Anais... Piracicaba:FEALQ, 1993, p.47-62.

PEREIRA, J. M.; COELHO DA SILVA, J. F. da. Efeito da adição de uréia e biureto sobre as características e valor nutritivo da silagem de milho. Rev. Soc. Bras. Zoot., Viçosa, MG. 5(2): 188-209, 1976.

PIRES, A. J. V.; CARVALHO, G. G. P. de.; GARCIA, R.; CARVALHO Jr, J. N. de.; RIBEIRO, L. S. O.; CHAGAS, D. M. T. Capim-elefante ensilado com casca de café, farelo de cacau ou farelo de mandioca. R. Bras. Zootec., v.38, n.1, p.34-39, 2009.

PIZARRO, E. A. Conservação de forragem. I. Silagem. Inf. Agropec. 4(47): 20-30. 1978.

REZENDE, A. V.; EVANGELISTA, A. R. Efeito da mistura da planta de girassol (Helianthus anuus L.) durante a ensilagem de capim elefante (Pennisetum purpureum Schum) no valor nutritivo da silagem. Revista Brasileira de Zootecnia, Viçosa, v. 31, p. 1839-1943, 2002.

RODRIGUES, R. Qualidade bromatológica de silagens de capim elefante e cana-deaçúcar aditivadas com raspa de batata. 2005. 77 f. Dissertação (Mestrado) - Universidade José do Rosário Vellano, Alfenas, 2005.

RODRIGUES, L. R. A., RODRIGUES, T. J. D. Ecofisiologia de plantas forrageiras. In: CASTRO, P. R. C., FERREIRA, S. O., YAMANDA, T. (Ed.) Ecofisiologia da produção agrícola. Piracicaba:POTAFÓS, 1987, p.203-230.

RODRIGUES, L.R.A., MONTEIRO, F.A., RODRIGUES, T.J.D. Capim elefante. In: PEIXOTO, A.M., PEDREIRA, C.G.S., MOURA, J.V., FARIA, V.P. (Eds.) Simpósio sobre manejo da pastagem, 17, Piracicaba, 2001. 2a edição. Anais... Piracicaba:FEALQ, 2001, p.203-224. 
REZENDE, A. V. de.; A. L.; GASTALDELlO Jr, A. L.; A. R. VALERIANO, A. R.; A. O. CASALI, A. O.; L. T. MEDEIROS, L. T.; RODRIGUES, R. Uso de diferentes aditivos em silagem de capim-elefante. Ciênc. agrotec., Lavras, v. 32, n. 1, p. 281-287, jan./fev., 2008.

ROSA, G. de A. Rendimento e valor nutritivo do capim Elefante (Pennisetum purpureum, Schum.) c. v. Cameroon. Lavras, ESAL, 1983. 115 p. (Tese de Mestrado).

SANTOS, E. M; ZANINE, A. M. Silagem de gramíneas tropicais. Colloquium Agrariae, v. 2, n.1, p. 32-45, Mar. 2006.

SILVA, J. C.; LEÃO. M. I. Fundamentos de Nutrição dos Ruminantes. Piracicaba, Livroceres, p.190-236.1979.

SILVEIRA, A.C.; LAVEZZO, W.; TOSI, H. et al. Avaliação química de silagens de capim elefante ( Pennisetum purpureum Schum. ) submetidas a diferentes tratamentos. $R$. Bras. Zootec., v.8, n.2, p.287-300,1979.

SILVEIRA, A.C.; LAVEZZO, W.; SILVEIRA FILHO, S. et al. Consumo de silagens de capim elefante ( Pennisetum purpureum Schum.). submetidos a diferentes tratamentos. $R$. Bras. Zootec., v.9, n.2, p.306-320, 1980.

SILVEIRA, A.C. Técnicas para produção de silagem. In: SIMPÓSIO SOBRE MANEJO DE PASTAGENS, 2., 1975, Piracicaba. Anais... Piracicaba: ESALQ,1975. p. 156-180.

SOBRINHO, J.N.; MATTOS, H.B. de.; ANDRADE, J.B. de. et al. Silagem de capim elefante, em três estádios de maturidade, submetido ao emurchecimento. III - Valor nutritivo das silagens. Boletim da Industria Animal. v.55, n.2, p.127-138, 1998.

TCACENCO, F.A., BOTREL, M.A. Identificação e avaliação de acessos e cultivares de capim-elefante. In: CARVALHO, M.M., ALVIN, M.J., XAVIER, D.F., et al. (Eds) Capim elefante: produção e utilização. $2^{a}$ ed., revisada. Brasília:Embrapa-SPI e Juiz de Fora:Embrapa-Gado de Leite, 1997, p.1- 30.

TOSI, H. Ensilagem de gramíneas tropicais sob diferentes tratamentos. Botucatu, Fac. De Ciências Médicas e Biol., 1973. 107 p. (Tese Doutorado).

TOSI, H.; FARIA, V.P. de.; GUTIERREZ, L.C. et al. Avaliação do capim elefante, cultivar Taiwan-148, como planta para ensilagem. Pesquisa Agropecuária Brasileira, v.18, n.3, p.295-299, 1983.

WHITTENBURY, R.; MCDONALD, P.; BRYAN-JONES, D. J. A short review of some biochemical and microbiological aspects of silage. J. Sci. Fod and Agric., 18:441$44,1967$. 